Strategi Pengembangan Lembaga Pendidikan Islam

\title{
STRATEGI PENGEMBANGAN LEMBAGA PENDIDIKAN ISLAM DI DAERAH MINORITAS MUSLIM DAN KAWASAN ELITE
}

\author{
Bustanul Arifin \\ Fakultas Tarbiyah STAI Bustanul Ulum Lumajang \\ bungyasin@gmail.com
}

\begin{abstract}
Educational institutions today are very absolute existence for the smooth process of education, especially in Indonesia. Moreover, educational institutions are associated with the concept of Islam, Islamic educational institutions are a forum where education within the scope of Islam carries out its duties for the achievement of the ideals of the Muslim Ummah. Islamic educational institutions are one of the Islamic propaganda media, so the development of Islamic educational institutions in an area is an indicator of the development of Islam in the region. Indonesia is a country with a majority Muslim population, but its spread is only concentrated in the western part of Indonesia, while the eastern part of Indonesia is a region that is very minimal almost untouched by Islamic teachings, Islamic educational institutions. The purpose of the preparation of this paper is to find out the concept of Islamic educational institutions and their development strategies in Muslim minority and elite areas.
\end{abstract}

Keywords: Islamic Education, Minority, elite

\begin{abstract}
Abstrak
Lembaga pendidikan dewasa ini sangat mutlak keberadaannya bagi kelancaran proses pendidikan, khususnya di Indonesia. Apalagi lembaga pendidikan itu dikaitkan dengan konsep Islam, lembaga pendidikan Islam merupakan suatu wadah dimana pendidikan dalam ruang lingkup keislaman melaksanakan tugasnya demi tercapainya cita-cita umat Islam. Lembaga pendidikan Islam merupakan salah satu media dakwah Islam, sehingga berkembangnya lembaga pendidikan Islam di suatu daerah merupakan indikator dari berkembangnya Islam di wilayah tersebut. Indonesia merupakan Negara dengan mayoritas penduduknya beragama Islam, namun penyebarannya hanya terpusat di wilayah Indonesia bagian barat, sementara wilayah bagian timur Indonesia menjadi wilayah yang sangat minim hampir tidak tersentuh ajaran Islam, lembaga pendidikan Islam. Tujuan dari penyusunan makalah ini adalah untuk mengetahui konsep lembaga pendidikan islam dan strategi pengembangannya di wilayah muslim minoritas dan kawasan elite.
\end{abstract}

Kata Kunci : Pendidikan Islam, Minoritas, elite

Falasifa, Vol. 10 Nomor 2 September 2019 | 1 
Bustanul Arifin

\section{PENDAHULUAN}

Pendidikan Islam di Indonesia telah ada sejak masuknya Islam ke Indonesia. Sejarah pendidikan Islam di Indonesia berjalan seiring dengan berkembangnya Islam itu sendiri. Hal ini karena setiap ada komunitas Muslim bertemu, maka di sana ada pendidikan Islam. Selanjutnya setelah masyarakat Islam telah terbentuk, maka yang menjadi perhatian utama adalah membangun rumah ibadah yaitu masjid,. Karena umat Islam diperintahkan untuk melaksanakan sholat lima waktu sehari semalam dan sangat dianjurkan untuk melaksanakannya secara berjamaah di masjid. Seiring dengan pertambahan populasi umat Islam di Indonesia, berkembang pula lembaga-lembaga pendidikan Islam. Lembaga merupakan salah satu komponen yang terpenting dan memegang peranan besar dalam pelaksanaan pendidikan. Secara umum ada tiga lembaga pendidikan, yaitu formal, informal, dan nonformal. Ketiga lembaga tersebut harus bersinergi dalam memberikan pendidikan untuk menciptakan manusia yang berbudi baik oleh karena itu strategi pengembangan pendidikan islam harus dijalankan dengan terstruktur agar pendidikan islam di indonesia semakin berkembang khususnya dikawasan muslim minoritas dan kawasan elite.

\section{PEMBAHASAN}

\section{A. Konsep Strategi Pengembangan Lembaga Pendidikan Islam}

\section{Konsep Lembaga Pendidikan Islam}

Kata "lembaga" dalam bahasa inggris berarti institution. Koentjaraningrat menerjemahkan institution dengan kata pranata, dan istilah lembaga disamakan dengan kata institute. Pranata adalah sistem norma atau aturan-aturan mengenai aktifitas masyarakat yang khusus, sedangkan lembaga atau institute adalah badan atau organisasi yang melaksanakan itu. Menurut Koentjaraningrat, kedua kata tersebut dibedakan karena mempunyai arti yang juga berbeda. ${ }^{1}$ Penekanan dari kedua kata tersebut bahwa jika pranata adalah sistem perilaku atau norma-norma masyarakat, sedangkan lembaga adalah perwujudan dari norma-norma atau perilaku masyarakat.

Menurut Horton dan Hunt yang dikutip oleh Hanun Asrohah dalam bukunya yang berjudul Pelembagaan Pesantren, lembaga sosial muncul sebagai hasil dari 
kehidupan yang tidak terencanakan. Masyarakat berusaha mencari cara yang mudah untuk memenuhi kebutuhan mereka sampai ditemukan pola-pola yang terjadi secara berulang-ulang dan menjadi standar kebiasaan. ${ }^{2}$

Kebiasan-kebiasaan yang telah berpola kemudian ditetapkan sebagai aturanaturan yang harus dilaksanakan oleh setiap anggota dari masyarakat melalui proses konsesus. Lembaga menurut bahasa adalah "badan" atau "organisai" tempat berkumpul. $^{3}$ Lembaga pendidikan menurut Ahmad D. Marimba adalah organisasi atau kelompok manusia yang karena satu dan lain hal memikul tanggung jawab pendidikan kepada si terdidik sesuai dengan badan tersebut. ${ }^{4}$

Lembaga pendidikan Islam ialah suatu bentuk organisasi yang diadakan untuk mengembangkan lembaga-lembaga Islam yang baik, yang permanen, maupun yang berubah-ubah dan mempunyai pola-pola tertentu dalam memerenakna fungsinya, serta mempunyai struktur tersendiri yang dapat mengikat individu yang berada dalam naungannya, sehingga lembaga ini mempunyai kekuatan hokum sendiri. ${ }^{5}$

Berdasarkan pengertian di atas dapat dipahami bahwa lembaga pendidikan Islam adalah tempat atau organisasi yang menyelenggarakan pendidikan Islam, yang mempunyai struktur yang jelas dan bertanggung jawab atas terlaksananya pendidikan Islam. Oleh karena itu, lembaga pendidikan Islam tersebut harus dapat menciptakan suasana yang memungkinkan terlaksananya pendidikan dengan baik, menurut tugas yang diberikan kepadanya, seperti sekolah (madrasah) yang melaksanakan proses pendidikan Islam.

\section{Lembaga Pendidikan Islam Indonesia.}

\section{a. Lembaga Pendidikan Pesantren}

Pesantren adalah satu-satunya lembaga pendidikan Islam tradisional yang samapai saat ini masih menjaga kelestarian tradisi-tradisi masa lalu, karena selain pesantren hampir tidak ada lembaga pendidikan, khususnya lembaga pendidikan Islam, yang masih menggunakan sistem pendidikan tradisional seperti pesantren. Meskipun saat ini mulai banyak pesantren yang mengubah wajahnya menjadi lebih

2Asrohah, Pelembagaan Pesantren, ,23.

3 Depdikbud, (1994). 851

4 Marimba, D. (1987), 56

5 Muhaimin, (1993). 286 


\section{Bustanul Arifin}

modern, namun tetap saja masih ada bagian-bagian yang tak bisa dihilangkan sama sekali dari sifat ketradisionalan pesantren, yaitu pola dan gaya kepemimpinannya.

Secara sosio-historis pesantren dipandang sebagai lembaga pendidikan Islam tertua di Indonesia yang didirikan oleh para Ulama (kiai). Pesantren didirikan dalam rangka mendidik masyarakat untuk memahami dan melaksanakan ajaran Islam, dengan menekankan pentingnya moral keagamaan sebagai pedoman hidup. Pengertian tertua dalam hal ini, karena pesantren adalah lembaga yang telah lama hidup ratusan tahun yang lalu tepatnya abad 14 M. dan sampai saat ini masih eksis, bahkan telah menjadi bagian yang mendalam dari sistem kehidupan sebagian besar umat Islam di Indonesia dan turut mewarnai dinamika bangsa Indonesia.

Sebelum membahas kapan pertama kali pesantren didirikan di Indonesia, terlebih dahulu perlu melacak asal-mula Islam masuk di Indonesia. Dalam hal ini para ahli sejarah saling berbeda pendapat, sebagian memperkirakan masuknya Islam ke Indonesia dimulai sejak abad ketujuh, sebagian lain memperkirakan bahwa Islam telah mulai berkembang di Indonesia sekitar abad 11, dengan salah satu bukti yang paling kuat, yaitu ditemukannya batu nisan Fathimah binti Maimun bin Hibatullah yang wafat tahun $475 \mathrm{H}$ atau tahun $1082 \mathrm{M}$. di Leran Gersik Jawa Timur. ${ }^{6}$

Terlepas dari perbedaan seputar kapan masuknya Islam di Indonesia, namun terjadinya kontak yang lebih intens antara budaya Hindu-Budha dan Islam dimulai sekitar abad 13.7 Jalur Islam semakin memperoleh bentuknya ketika para Wali Songo mulai melakukan penetrasi dan berinteraksi dengan kekuasaan, yaitu ketika terjadi pergantian kekuasaan dari Majapahit ke Kesultanan Demak Bintoro yang dipimpin oleh Raden Fattah pada abad 15. Pada masa ini nilai-nilai Islam berangsur-angsur menggantikan budaya Hindu. Pada saat itu Islamisasi masyarakat jawa yang dilakukan oleh Wali Songo berjalan sangat lempang. Pengaruh Islam menyebar hampir keseluruh pulau jawa, kecuali beberapa daerah yang terletak di pedalaman. 8

6 Anason, Sejarah Masuknya Islam di Jawa, dalam Darrari Amin (ed), "Islam dan Kebudayaan Jawa", (Yogyakarta : Gajah Mada, cet. II, 2002), 28.

7 Anason, Sejarah Masuknya Islam.

8 Anason, Sejarah Masuknya Islam.

Falasifa, Vol. 10 Nomor 2 September 2019 | 4 
Namun yang unik dikemukakan adalah kondisi yang berbeda antara penyebaran Islam di jazirah Arab dan di Indonesia. Perbedaan itu bisa dilihat dari beberapa tulisan sejarah yang menyebutkan bahwa penyebaran Islam di Timur Tengah dengan jalan penaklukan dan penjajahan dengan kata lain penerapan hukum Islam (fikih). Berbeda dengan konteks Indonesia, yang dilandasi dengan nilai-nilai toleran dan nilai-nilai budaya, bukan penerapan hukum fikih, tetapi memasukkkan nilai-nilai esensial Islam dalam kehidupan masyarakat. Hal ini karena Islam yang didatangkan dari India dan Persia oleh para Wali Songo tidak bisa lepas dari ajaran-ajaran dasar tassawuf. ${ }^{9}$

Keberadaan Wali Songo yang juga pelopor pendirinya pesantren dalam perkembangan Islam di Jawa sangatlah penting sehubungan dengan peranannya yang sangat dominan. Wali Songo melakukan suatu proses yang tak berujung, gradual, dan berhasil dalam menciptakan satu tatanan masyarakat santri yang saling damai dan berdampingan. Selanjutnya, oleh beberapa Wali Songo yang menggunakan pesantren sebagai tempat menyebarkan dan mengajarkan agama Islam kepada masyarakat Jawa diintegrasikan dengan pendekatan yang berkesesuaian dengan filsafat hidup masyarakat Jawa. ${ }^{10}$

Secara umum tujuan didirikan pesantern pada dasarnya dibagi menjadi dua, yaitu : tujuan umum, membimbing santri untuk menjadi manusia yang berkepribadian Islam yang sanggup menyalurkan keilmuannya dalam masyarakat luas dengan ilmu dan amalnya. Tujuan khusus, mempersiapkan para santri uintuk menjadi orang yang ahli dan menguasai ilmu keagamaan yang kemudian diamalkan dalam masyarakat sekitar tempat hidupnya. ${ }^{11}$

Dalam perspektif sosiologis pesantren dipandang sebagai satu relaitas sosial budaya yang memiliki banyak persamaan dan perbedaan sekaligus antar masingmasing pesantren pada umumnya dan banyak perbedaan di tengah perubahan kehidupan masyarakat indonesia. Menurut Abduahman Wahid, ${ }^{12}$ nilai perbedaan pesantren disebut sebagai suatu subkultur di tengah-tengah masyarakat luas.

9 Faiqoh, Nyai Agen Perubahan di Pesantren. (Jakarta : Kurcica, 2003), 151.

10 Faiqoh, Nyai Agen Perubahan. 151.

11 Amin Haedari. Panorama Pesantren dalam Cakrawala Modern. (Jakarta : Diva Pustaka, 2004).

12 Gus Dur "Pesantren": (WWW. Gus Dus Net. Libanon 2002).

Falasifa, Vol. 10 Nomor 2 September 2019 | 5 


\section{Bustanul Arifin}

Perbedaan antar masing-masing pesantren, karena para kiai betul-betul memperhatikan pertalian nasab dalam mengembangkan pesantrennya. Kalaupun tidak berdasarkan nasab biasanya berkaitan dengan ikatan emosional yang sangat kuat antara kiai dan santri, sehingga cenderung untuk mempertahankan kebiasaan dan tradisi yang diwariskan oleh kiainya.

Pondok pesantren dalam bacaan teknis merupakan suatu tempat yang dihuni oleh para santri. Pernyataan ini menunjukkan makna pentingnya ciri-ciri pondok pesantren sebagai lingkungan pendidikan yang integral. Sistem pendidikan pesantren sebetulnya sama dengan sistem yang digunakan Akademi Militer, yakni dicirikan dengan adanya sebuah bangunan beranda yang di situ seseorang dapat mengambil pengalaman integral. Dibandingkan dengan lingkungan pendidikan parsial yang ditawarkan sistem pendidikan sekolah umum di Indonesia sekarang ini, sebagai budaya pendidikan nasioanal, pondok pesantren mempunyai kultur yang unik. Karena keunikannya, pondok pesantren digolongkan kedalam subkultur tersendiri dalam masyarakat Indonesia. ${ }^{13}$

Pesantren disebut sebagai subkultur, menurut Abdurraman Wahid,karena ada tiga elemen yang membentuk pondok pesantren, yaitu, pertama, pola kepemimpinan pondok pesantren yang mandiri tidak terkooptasi oleh Negara, kedua, kitab-kitab rujukan umum yang selalu digunakan dari berbagai abad, dan ketiga, sistem nilai yang digunakan adalah bagian dari masyarakat luas. ${ }^{14}$

Pesantren secara ideal mempunyai dua fungsi; mobilitas sosial dan pelestarian nilai-nilai etik serta pengembangan tradisi intelektual. Fungsi pertama menempatkan pendidikan pesantren sebagai sarana dan instrumen melakukan sosialisasi dan ternsformasi nilai agar umat mampu melakukan mobilisasi sosial berdasarkan pada nilai agama. Fungsi kedua lebih bersifat aktif dan progresif, di mana pesantren dipahami tidak saja sebagai upaya mempertahankan nilai dan melakukan mobilisasi sosial, lebih dari itu merupakan sarana pengembangan nilai dan ajaran. Ini menuntut terjadinya interdependensi, otonomi dan pembebasan dari setiap belenggu baik struktural maupun kultural karena pengembangan intelektual

13 Abdurrahman Wahid, Pondok Pesantren Masa Depan, dalam Pesantren Masa Depan : Wacana Pemberdayaan dan Tansformasi Pesantren, (Jakarta : Pustaka Hidayah, 1999). 13

14 Wahid, Pondok Pesantren Masa Depan,.14

Falasifa, Vol. 10 Nomor 2 September 2019 | 6 
bisa terjadi jika menusianya independen dan tidak terikat baik secara fisik maupun mental. $^{15}$

Pesantren, sebagai suatu subkultur, lahir dan berkembang seiring dengan derap langkah perubahan-perubahan yang ada dalam masyarakat global. Perubahan-perubahan yang terus berggulir itu, cepat atau lambat, pasti akan mengimbas pada komunitas pesantren sebagai bagian dari masyarakat dunia, meskipun tidak dikehendaki. Karenanya, tidaklah berlebihan jika A. Sahal Mahfudz menyebutkan bahwa ada dua potensi besar yang dimilki pesantren, yakni potensi pengembangan masyarakat dan potensi pendidikan. ${ }^{16}$

Dalam kaitan ini, bila ditilik dari kehadirannya, menarik kiranya untuk disimak bahwa institusi pesantren ternyata memilki keunikan tersendiri bila dibandingkan dengan perannya dewasa ini. Dalam hubungannya dengan potensi di atas, kehadiran pesantren disebut unik sekuarang-kurangnya karena ada dua alasan sebagai berikut.

Pertama, pesantren dilahirkan untuk memberikan respon terhadap situasi dan kondisi sosial suatu masyarakat yang tengah dihadapkan pada runtuhnya sendi-sendi moral, melalui transformasi nilai yang ditawarkannya (amar ma'ruf dan nahy munkar). Kehadirannya, dengan demikian bisa disebut sebagai agen perubahan sosial (agent of social change), yang selalu melakukan kerja-kerja pembebasan (liberation) pada masyarakatnya dari segala keburukan moral, penindasan politik, pemiskinan ilmu pengetahuan, dan bahkan dari pemiskinan ekonomi. Institusi pesantren, dengan begitu, mengesankan telah berhasil mentransformasikan masyarakat di sekitarnya dari keburukan menuju kesalihan, dan dari kefakiran menuju pada kemakmuran atau kesejahteraan. Oleh karenanya, kehadiran pesantren menjadi seuatu keniscayaan sebagai bentuk institusi yang dilahirkan atas kehendak dan kebutuhan masyarakat. Dengan kesadarannya, pesantren dan masyarakat telah membentuk hubungan dengan harmonis, sehingga komunitas pesantren kemudian diakui menjadi bagian tak terpisahkan atau sub- 


\section{Bustanul Arifin}

kultur dari masyarakat pembentuknya. Pada tataran ini, pesantren telah berfungsi sebagi pelaku pengembangan masyarakat. ${ }^{17}$

Kedua, salah satu misi awal didirikannya pesantren adalah menyebarluaskan informasi ajaran tentang universalitas Islam ke seluruh pelosok Nusantara yang berwatak pluralis, baik dalam dimensi kepercayaan, budaya maupun kondisi sosial masyarakat.18 Melalui medium pendidikan yang dikembangkan para Wali dalam bentuk pesantren, ajaran Islam lebih cepat membumi di Indonesia. Hal ini tampaknya menjadai fenomena tersendiri bagi keberadaan pesantren sebagi bagian dari historisnya di Indonesia yang dapat menjelaskan elanvital peran pesantren tatkala melahirkan kader-kadernya untuk dipersiapkan memasuki segala sistem kehidupan masa itu.

Dengan institusi pesantren yang dibangunnya, para Wali berhasil menginternalisasikan nilai-nilai Islam dalam lingkungan masyarakat. Idealisasi bangunan masyarakat yang ditempuh adalah sebuah masyarakat muslim yang inklusif, egaliter, patriotik, luwes dan bergairah terhadap upaya-upaya transformative. Misi kedua ini lebih berorientasi pada peran pesantren sebagai sebuah institusi pendidikan Islam.

\section{b. Madrasah}

Sebelum masa kemerdekaan, lembaga pendidikan yang ada di Indonesia dikelola oleh Pemerintah Kolonial. Karel A. Steenbrink dalam penelitiannya yang berjudul "Pesantren, Madrasah, Sekolah menjelaskan perbedaan antara pendidikan Kolonial dengan pendidikan Islam Indonesia yang tradisional (baca pesantren) terletak pada metode, isi dan tujuan. Pendidikan yang dikelola kolonial berpusat pada pengetauan dan ketrampilan dunia, yaitu pendidikan umum. Sedangkan lembaga pendidikan Islam lebih ditekankan pada pengetahuan dan ketrampilan yang berguna bagi penghayatan agama, dan masih banyak lagi perbedaanperbedaan yang mencolok di antara keduannya.19

17 Marzuki, Pesantren Masa Depan. 202.

18 Marzuki, Pesantren Masa Depan. 202.

19 Karel A. Steenbrink, Pesantren, Madrasah, Sekolah; Pendidikan Islam dalam Kurun Modern, (Jakarta; LP3ES, 1986), 24.

Falasifa, Vol. 10 Nomor 2 September 2019 | 8 
Dilihat dari segi bahasa, madrasah brasal dari bahasa Arab yang berarti 'tempat belajar', padanan madrasah dalam bahasa Indonesia adalah sekola Kata madrasah di Arab ditujukan pada sekolah-sekolah secara umum, berbeda dengan konteks Indonesia yang mengartikan madrasah sebagai lembaga di mana ilmuilmu keislaman diajarkan. ${ }^{20}$

Menurut Munir Uddin Ahmed yang juga dikutip oleh Azyumardi Azra, sebelum munculnya madrasah, pendidikan Islam sejak masa Nabi dilaksanakan di Masjid dan rumah-rumah guru, pendidikan dilaksanakan dalam halaqah, majlis alTadris, dan kuttab. ${ }^{21}$

Sebelum masa kemerdekaan, lembaga pendidikan yang ada di Indonesia dikelola oleh Pemerintah Kolonial Belanda. Karel A. Steenbrink dalam penelitiannya yang berjudul "Pesantren, Madrasah, Sekolah menjelaskan perbedaan antara pendidikan Kolonial dengan pendidikan Islam Indonesia yang tradisional (baca pesantren) terletak pada metode, isi dan tujuan. Pendidikan yang dikelola kolonial berpusat pada pengetauan dan ketrampilan dunia, yaitu pendidikan umum. Sedangkan lembaga pendidikan Islam lebih ditekankan pada pengetahuan dan ketrampilan yang berguna bagi penghayatan agama, dan masih banyak lagi perbedaan-perbedaan yang mencolok di antara keduannya. ${ }^{22}$

Di Indonesia madrasah baru muncul sekitar tahun 1909 M di Padang dengan nama Madrasah Adabiyah yang didirikan oleh Syekh Abdullah Ahmad, yang kemudian pada tahun 1915 madrasah ini menjadi HIS Adabiyah yang tetap mengajarkan agama.23 Selain itu didirikan juga Madrasah School di Batu sangkar yang didirikan oleh Syekh M. Thaib Umar pada tahun 1910 yang hanya berumur tiga tahun dan kemudian dibuka kembali oleh Mahmud Yunus pada tahun 1918 yang kemudian pada tahun 1923 berganti nama menjadi Diniyah School. Pada tahun yang hampir bersamaan, yaitu sekitar tahun 1915 Zainuddin Labai al-Yunusi

20 Haidar Putra Daulay, Sejarah Pertumbuhan dan Pembaruan Pendidikan Islam di Indonesia, (Jakarta: Kecana, 2009), 94.

21 Azyumardi Azra, Jaringan Ulama Timur Tengah dan Kepulauan nusantara Abad XVII dan XVIII; Melacak akar-akar Pembaruan Pemikiran Islam Indonesia, (Bandung; Mizan,, 1998)11.

22 Karel A. Steenbrink, Pesantren, Madrasah, Sekolah; Pendidikan Islam dalam Kurun Modern, (Jakarta; LP3ES, 1986), 24.

23 Haidar Putra Daualy, Sejarah Pertumbuhan dan Pembaharuan Pendidikan Islam di Indonesia, (Jakarta: Kencana, 2009),97. 


\section{Bustanul Arifin}

juga mendirikan Madrasah Diniyah di Padang Panjang. Madrasah inilah yang kemudian yang berkembang di Indonesia yang merupakan bagian dari pesantren atau surau, maupun berdiri diluarnya. ${ }^{24}$

Dengan berdirinya madrasah-madrasah di Wilayah Sumatra bagian barat seperti Padang, maka di Jawa yang merupakan pusat perkembangan pesantren sebagai pusat pengembangan ilmu-ilmu keislaman pun mengalami hal yang sama. Organisasi Islam seperti Muhammadiyah dan Nahdlatul Ulama (NU) adalah dua organisasi yang bergerak di bidang sosial kemasyaraktan yang sangat berjasa pada perkembangan Madrasah di Jawa. Hal ini dapat dilihat dari banyaknya Madrasah dan sekolah Islam yang berkembang di Jawa, Muhammadiyah misalnya pada tahun 1925 taleh memiliki 8 Hollends inlands School, sebuah sekolah guru di Yogyakarta, 32 Sekolah Dasar, sebuah schakel school dan 14 madrasa $^{25}$

Demikian juga NU yang mengembangkan Madrasah dibawah lembaganya yang bernama Ma'arif NU. Mulai Madrasah Ibtida'yah (6 tahun), Madrasah Tsanawiyah (3 tahun), Madrasah Aliyah (3 tahun) dan Sekolah Tinggi Agama Islam yang saat ini telah tersebar luas keseuruh wilayah di Indonesia. Selain dua organisasi Islam yang telah disebutkan di atas, Madarasah juga dikembangkan oleh individu-individu yang mempunyai kepedulian terhadap perkembangan Islam di Indonesia (khususnya Jawa).

\section{B. Strategi Pengembangan Lembaga Islam di Daerah Minoritas Muslim}

Islam mewajibkan umatnya untuk menyampaikan ajaran Islam kepada seluruh uamat manusia tanpa terkecuali,namun bukan berarti juga menghalalkan segala cara, seperti pemaksaan dan kekerasan. Islam adalah agama yang rahmatan lil alamiin, sehingga cara untuk menyampaikannya pun harus menggunakan dangan cara yang ramah dan kehadirannya dapat menjadi rahmat bagi seluruh umat manusia tanpa memandang perbedaan agama, kepercayaan, ras, suku dan bangsa.

Lembaga pendidikan Islam merupakan salah satu media dakwah Islam, sehingga berkembangnya lembaga pendidikan Islam di suatu daerah merupakan indicator dari berkembangnya Islam di wilayah tersebut. Indonesia merupakan Negara dengan

24 Haidar, Sejarah Pertumbuhan,

25 Haidar, Sejarah Pertumbuhan, 98.

Falasifa, Vol. 10 Nomor 2 September 2019 | 10 
mayoritas penduduknya beragama Islam, namun penyebarannya hanya terpusat di wilayah Indonesia bagian barat, sementara wilayah bagian timur Indonesia menjadi wilayah yang sangat minim hampir tidak tersentuh ajaran Islam, lembaga pendidikan Islam. Sehingga pengembangan lembaga pendidikan Islam di wilayah Indonesia wilayah barat relative lebih mudah karena selain mendapatkan kemudahan dari masyarakat sekitar yang mayoritas muslim juga didukung oleh respon positif masyarakat sekitar. Berbeda dengan yang terjadi di wilayah Indonesia bagian Timur yang masih sangat minim pemeluk muslimnya.

Lembaga pendidikan agama islam amat sulit memperolah siswa dari kalangan nonmuslim. Pendidikan islam bagi masyarakat nonmuslim bukan sekadar tidak menjadi kebutuhan mereka, melainkan lebih dari itu, pendidikan islam dipandang membahayan keyakinan mereka, sehingga harus dijauhi dan di hindari khususnya bagi merekayang masih kuat memigangi keyakinannya. Perepsi seperti ini wajar terjadi, dan umat islamyang kokoh keyakinannya terhadap akidah islam juga akan bersikap seperti itu. Mereka tidak akan melepas putra-putrinya memasuki lembaga pendidikan katilok, hindu, buddha, dan sebagainya.

Apakah pengalaman ini dapat ditiru dalam mengembangkan lembaga pendidikan islam didaerah-daerah kantong-kantong nonmuslim? Jawabannya tentu bisa, namun dengan syarat, yaitu pertama, karakter masyarakat nonmuslim tersebut memiliki kesadaran bahwa kemajuan lembaga pendidikan lebih utama daripada identitas regiliusnya; dan kedua, perkembangan lembaga pendidikan islam dapat mengungguli lembaga-lembaga pendidikan lainnya.

Dua syarat ini tentu sulit dipenuhi. Untuk memenuhi syarat yang kedua saja, luar biasa berat bagi lembaga pendidikan islam, apalagi rata-rata lembaga pendidikan islam itu tertinggal dari lembaga pendidikan non-islam. Apalgi lembaga pendidikan islam yang didasari motif dakwah itu sering kali menimbulkan dampak nigatif kendatipun masih ada juga dampat positifnya. Qomar mengatakan : "Moif dakwah dalam pendirian lembaga pendidikan islam membawa dampak positif dan negatif. Dampak positifnya adalah memiliki kekuatan besar untuk bertahan dan hidup (survie) meskipun jumlah siswanya hanya sedikit. Tidak ada kata menyerah dalam meneruskan keberadaan lembaga pendidikan. Sementara itu, segi negatifnya terkadang menimbulkan kondisi 


\section{Bustanul Arifin}

serba tidak teratur, serba tidak terencana, serba tidak terancang, serba tidak kompetitif, dan serba mengalami kemunduran".

Misi dakwah dan pendidikan islam perlu dikemas sebaik mungkin sehingga mengesnkan sebagai suatu kegiatan yang memberikan manfaat bukan hanya terhadap umat islam tetapijuga terhadap umat-umat yang lainnya. Bagai mana menjabarkan dakwahdan pendidikan islam bisa dirasakan orang-orang nonmuslimsebagai sesuatu kegiatan yang memberi manfaat bagi mereka. Abdul Munir Mulkhan menyatakan bahwa pengembangan dakwah dan pendidikan islam harus dilakukan secara dialogis, sehingga terbangun sisten budaya dan sistem sosial yang mendukung aktualisasi pesan global islam mengenai rahmatan lil alamin, Gerakan dakwah dan sebagin pendidikan sistem, harus merupakan gerakan totalitas berbagai aspek kehidupan. Maka amat penting untuk memahami realitas kehidupanmasyarakat yang di jadikan sarana dakwah dan pendidikan islam yang meliputi berbagai aspek.

Hal ini perlu di perhatikan oleh manajer khususnya yang tengah mengelola lembaga pendidikan isam, apapun bentuknya, baik madrasah, sekolah islam, maupun pesantren, yang berada di tengah-tengah masyarakat nonmuslim. Adapin secara rinci langkah-langkah atau setrategi-setrategi yang perlu ditempuh manajer tersebut adaah:

1. Menggerakkan seluruh pegawai untuk dapat memberika contoh keteladanan baik perbuatan maupun ucapan, baik disekolah/madrasash/ pesantren, di masyarakat maupun di ruma

2. Aktif menjalin komunikasi dengan masyarakat setempat agar lembaga pendidikan islam dapat diterima keberadaan nya dan minimal tidak dicurigai;

3. Aktif dalam kegiatan-kegiatan sosial di masyarakat sekitar lembaga pendidikan islam itu termasuk kegiatan kerja bakti, santunan, dll;

4. Mengemas kegiatan-kegiatan lembaga pendidikan islamyang dapat bermanfaat bagi masyarakat;

5. Memberlakukan semangat kinerja yang tinggi baik menyangkut kedisiplinan, ketertiban, keterampilan, dll;

6. Memberikan penguatan-penguatan pada usaha-usaha transformasi yang mengarah kepada prilaku yang baik dan profesional;

7. Meningkatkan pencapayan prestasi siswa, tenaga pendidik dan kependidikan, dan lembagapendidikan islam, baik prestasi akademik maupun prestasi nonakademik;

8. Meningkatkan publikasi terhadap prestasi-prestasi yang berhasil dicapai tersebut kepada masyarakat luas;

9. Mengkomunikasikan dan mensosialisasikan program-program kegiatan pendidikan yang sedang dilaksanakan; 
10. Membagun jaringan kerja sama dengan lembaga-lembaga lain untuk mendukung pengetahuan lembaga;

11. Memperkuat kekuatan pendanaan lembaga pendidikan islam;

12. Meningkatkan kelengkapan sarana dan prasana pendidikan;

13. Meningkatkan pengetahuan dan pemberdayaan sumber daya manusia;

14. Mebudayakan pelayanan prima kepada siapapun yang berkepentingan dengan lembaga; dan

15. Berusaha membangun image (image building) sebagi lembaga pendidikan yang memiliki beberapa keunggulan atau kelebihan-kelebihan. ${ }^{26}$

Untuk dapat mewujutkan strategi-strategi tersebut, seorang manajer harus melakukan penataan sejak awal sekali sambil merintis budaya belajar maupun budaya kerja yang kondusif mempengaruhi terhadap pendidik, dantenaga kependidikan maupun peserta didik.

\section{Strategi Pengembangan Lembaga Pendidikan Islam di Kawasan Elit}

Elite adalah orang-orang terbaik atau pilihan dalam suatu kelompok atau kelompok kecil orang-orang terpandang atau berderajat tinggi seperti kaum bangsawan, cendekiawan, dan sebagainya. ${ }^{27}$ Jadi kawasan elite adalah kawasan khusus yang terdiri dari keluarga orang-orang terpandang, seperti di Green Pamenang dan Gudang Garam Permai di Kota Kediri yang kebanyakan dihuni oleh para pejabat dan pengusaha.

Adalah hal yang wajar jika manusia menginginkan kemenangan dalam pertunjukan demi mempertahankan kebesaran dan kehormatan, lebih lagi ketika sampai pada kebenaran. Terkadang metode tersebut dalam Al-Qur'an diisyaratkan sebagai perintah berjihad demi agama Allah, karena misi dakwah bukan karena beban namun merupakan kewajiban yang harus terwujudkan. ${ }^{28}$

Azyumardi Azra (dalam Mujamil Qomar) melaporkan bahwa pada akhir abd ke 20 terdapat kecendurngan di kalangan masyarakat muslim. pertama, adalah mulai berkembangnya hasrat dan keinginan untuk memberikan posisi lebih besar kepada pemerintah dalam upaya memberdayakan pendidikan/perguruan agama dalam berbagai segi seperti kecendrungan 'menegerikan' madrassah-madrasah swasta, dan kedua, terjadinya konsolidasi sumber-sumber daya dan dana untuk membangun perguruan islam yang berkualitas. Melalui inisiatif dan dana sendiri, dan bahkan juga pinjaman

\footnotetext{
${ }^{26}$ Mujamil Qomar, Strategi Pendidikan Islam, 356-358

${ }^{27}$ Poerwodarminto, Kamus Umum Bahasa Indonesia, (Jakarta, Balai Pustaka, 2005), 433

${ }^{28}$ Muhammad Ali Hasyim, Kepribadian dan Dakwah Rasulullah dalam Kesaksian Al-Qur'an (Cet. I; Yogyakarta, Mutiara Pustaka, 2004), 75.
} 


\section{Bustanul Arifin}

komersial dari bank, semakin banyak kalangan muslim yang mendirikan sekolahsekolah islam unggulan, guna memenuhi tuntutan pasar seiring dengan pertumbuhan kelas menenga Dalam pandangan kalangan muslim, bukan saatnya lagi mendirikan sekolah-sekolah islam atau madrasah asal-asalan, dengan kualitas yang memprihatinkan. Sekarang saatnya mendirikan dan mendirikan lembaga pendidikan islam yang berkualitasyang akan dibeli oleh pasar yang kian terbentuk. ${ }^{29}$

Pada kenyataannya hingga sekarang perumahan mewah terus dibangun untuk memenuhi permintaan pasar terhadap hunian yang eksklusif terutama di kota-kota besar di Indonesia. Berbagai fasilitas pun dibangun guna menunjang keberadaan kawasan hunian. Pusat perbelanjaan modern dan mewah, sarana olah gara dan rekreasi, rumah sakit dan tidak ketinggalan adalah sekolah sehingga para pengembang perumahan mewah tidak sekedar merangkul yayasan sekolah, dipilih sekolah-sekolah favorit yang nantinya dapat bersinergi dengan keadaan lingkungan perumahan elite.

Qomar menyampaikan bahwa strategi yang perlu ditempuh dalam menghadapi masyarakat elite (1) pemperakarsa pendirian atau penyelenggaraan lembaga pendidikan islam itu seharusnya orang-orang yang ekonominya kuat seperti pengusaha besar, (2) lembaga pendidikan islam ini harus memiliki ikon keunggulan tertentu yang tidak dimiliki oleh lembaga pendidikan lain di sekitarnya, khususnya menyangkutkekokohan intlektual dan kepribadian; (3) mengupayakan secara serius dan berkesinambungan dalam memperkokoh sumber daya manusia khususnya para pendidiknya sehingga semua pegawainya benar-benar profesional; (4) Mampu menarik dukungan, pengakuan, rasa simpati dan pilihan dari masyarakat luas kepada lembaga pendidikan islam tersebut; (5) Menghasilkan lulusan-lulusan yang kerap memenangkan kompetisi, baik dalam memasuki lembaga pendidikan berikutnya yang bonafide, bersaing prestasi di kelas/di sekolahan lain yang lebih tinggi tingkatannya, maupun pada kasus-kasus tertentu dalam memasuki bursa kerja. ${ }^{30}$

Sekolah elite pun bermunculan di beberapa kawasan perumahan mewa Sebut saja Sekolah Ciputra, Sekolah Harapan Bangsa dan lain sebagainya. Kawasan hunian mewah, terus mencoba membangun lembaga pendidikan seperti sekolah di Summarecon

29 Mujamil Qomar, Strategi Pendidikan Islam, 358

${ }^{30}$ Mujamil Qomar, Strategi Pendidikan Islam, 356-358 359

Falasifa, Vol. 10 Nomor 2 September 2019 | 14 
Bekasi sebuah kawasan perumahan elite di Timur Jakarta. Berikut beberapa sekolah "elite" yang berkembang : 31

1. Sekolah Harapan Bangsa. Beroperasi sejak tahun 2005. Saat ini memiliki 4 gedung di perumahan Kota Modern dan Moderhill. Konsep Sekolah Harapan Bangsa (SHB) adalah mendidik siswa-siswi hingga berprestasi dalam pengetahuan akademik (Knowledge) dan non akademik, mempunyai prinsip keimanan yang teguh (Faith), serta memiliki pribadi yang berkarakter kuat (Character) saat berada ditengah masyarakat.

2. Sinarmas World Academy (SWA). Sekolah internasional yang beroperasi sejak 2008 di BSD City. Memiliki visi untuk menciptakan masa depan komunitas pembelajar yang dinamis yang meliputi Asia dan terlibat secara global. Sementara misinya adalah Terlibat, Bertindak, dan Berkembang. Menggunakan pengantar bahasa Inggris sedangkan bahasa pendukung adalah Mandarin dan bahasa Indonesia. SWA menggunakan kurikulum Internatioinal Baccalaureate (IB) yang sudah mendapatkan otoritas penuh untuk IB Primary Years Programme (IB MYP) untuk Pre-Kindergarten hingga kelas 5, IB Niddle Years Programme (IB MYP) untuk kelas 6-10, dan IB Diploma Programme (IB DP) untuk kelas 11-12.

3. Sekolah Citra Berkat. Berada di perumahan CitraRaya menyediakan sarana pendidikan TK dan SD. Melalui pendirian Sekolah Citra Berkat, Ciputra ingin membagikan berkat bagi anak-anak Indonesia agar mereka dapat mempersiapkan diri menjadi entrepreneur masa depan, sekaligus membentuk generasi yang lebih siap menghadapi era globalisasi. Untuk tujuan inilah, dengan berdasarkan prinsip-prinsip Kristiani yaitu melayani dan mengasihi, Sekolah Citra Berkat memfokuskan pada pembangunan mindset dan karakter yang sesuai dengan kebutuhan masyarakat global di era abad 21.

4. Sekolah Fajar Hidaya Berlokasi di Sentul City terdiri atas jenjang pendidikan SD dan SMP. Menggunakan kurikulum nasional plus, yang berbasis Islam. Siswa juga diarahkan untuk menguasai dua bahasa yakni Inggris dan Arab, sehingga selepas

\footnotetext{
${ }^{31}$ Umaroni dan Chasmin, Wawancara tanggal 19 Nopember 2016 (pada acara reuni akbar Madrasah Aliyah Tribakti Kediri).
} 
Bustanul Arifin

sekolah mereka dapat melanjutkan keluar negeri baik ke Eropa maupun ke Timur Tenga

5. Sekolah Islam Al Azhar Bekasi. Beroperasi pada tahun ajaran 2013-2014 di Summarecon Bekasi dengan membuka jenjang pendidikan SMP dan SMA, yang masing-masing terdiri atas 4 kelas paralel. Tahap 1 yang dibangun di atas lahan seluas $1 \mathrm{Ha}$, terdiri dari bangunan 5 lantai dengan 1 lantai basement dan 1 lantai atap. Dengan Fasilitas kelas dilengkapi dengan AC dan LCD, Lab Bahasa, Komputer, Musik, Biologi, Fisika, Kimia, Perpustakaan, Ruang OSIS/EKSKUL, Rapat Guru, Koperasi, Jam'iyyah, Klinik / UKS, Musholla, Kantin (150 orang) dan Aula (500 orang), Sarana Olahraga yang terdiri dari Lapangan Basket, Volley, Futsal, Badminton dan Tenis Meja.

Di Batur Kabupaten Klaten, daerah industri pengecoran logam yang rata-rata memiliki pabrik ${ }^{32}$ dan gaya hidupnya elite berdiri pesantren kalong dan Building School. Pesantren Kalong adalah model pesantren yang melaksakan kegiatan kepesantrenan di malam hari saja, sementara di siang hari para santri bebas melakukan aktivitas atau ibadah lain, pesantren ini menampung siswa yang pagi harinya bersekolah umum (SMP, SMA, maupun SMK) dan para pekerja (mulai buruh tani dan pengecoran logam) dari berbagai daerah. Sementara Buiding School berada di kawasan Sangkal Putung, kawasan pertokoan besar dan perkantoran di pusat kota Klaten.

Sejak tahun 2002, Pesantren Lirboyo kompleks "HY" (didirikan oleh KH. Ya'kub pada era 1970) ${ }^{33}$ membuka cabang di Talun Sukorame Mojoroto Kediri di kawasan perumahan wilis yang rata-rata dihuni pegawai Pemkot, Pemkab dan Perbankan yang melayani para siswa ngalong dan privat keliling. Para santri senior membimbing anak-anak penduduk setempat sesuai dengan permintaan, baik di lingkungan pondok atau harus mendatangi rumah.

Apabila tidak mungkin mendirikan sekolah atau pesantren sebagaimana yang penulis laporkan di atas, perlu terobosan dengan mendirikan LPI yang "kedengarannya aneh" semisal TPA dan NAF. Tempat Penitipan Anak (TPA) sebagaimana yang diupayakan Pondok Pesantren Al Falah di Sumberdoko Kabupaten Kediri yang berada

32 Suyadi, Guru SMPN Weru Sukoharjo, Wawancara, tanggal 25 Nopember 2016

33 Ibrahim, Abdurrahman bin Hafidz, Tim Penyusun Buku Memori, Menjelang Satu Abad Lirboyo, (Kediri, Sumenang, 2009), 201.

Falasifa, Vol. 10 Nomor 2 September 2019 | 16 
di kawasan pekerja pabrik dan perkantoran di Kediri sebagai wahana baru menyelenggarakan pendidikan islam, ${ }^{34}$ sementara NAF adalah sekolah islam terpadu yang berada di jalan Penanggungan, berada diantara sekolah sekolah favorit (seperti SMP 4, SMA 2, SMA 1 dan SMK 1) dan lingkungan Pondok Pesantren Lirboyo Kota Kediri.

Dalam keadaan yang bagaimanapun hendaknya selalu berusaha melakukan transformasi pengetahuan agama, baik sendirian maupun bersama-sama dalam sebuah majelis atau lembaga. Agama Islam berdiri tegak diatas upaya saling menasihati, maka harus selalu saling menasihati diantara masing-masing individu muslim, agama adalah nasihat yang wajib dilakukan oleh saetiap muslim sesuai kemampuannya. Sabda Nabi :

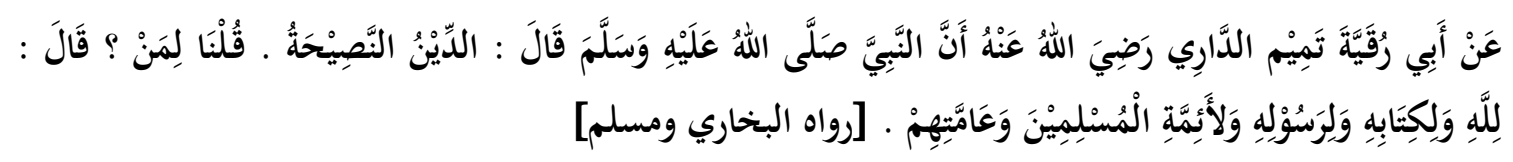

Terjemmahnya : "Dari Abu Ruqoyah Tamim Ad Daari radhiallahuanhu, sesungguhnya Rasulullah Shallallahu'alaihi wasallam bersabda : Agama adalah nasehat, kami berkata : Kepada siapa ? beliau bersabda : Kepada Allah, kitab-Nya, Rasul-Nya dan kepada pemimpan kaum muslimin dan rakyatnya”. (Riwayat Bukhori dan Muslim)

\section{KESIMPULAN}

Lembaga pendidikan islam adalah lembaga transformasi pengetahuan keagamaan yang didirikan oleh pemerintah maupun swasta dalam bentuk pondok pesantrean, madrasah dan sekolah. Strategi pengembangannya di wilayah muslim minoritas dengan bekerja sama dengan pemerintah setempat, disamping harus senantiasa mencari simpati sebagaimana yang dicontohkan Nabi SAW dan para walisongo dalam upaya mengembangkan ajaran islam. Strategi pengembangan lembaga pendidikan islam di kawasan elite adalah mengupayakan kerjasama yang baik dengan para pengusaha properti dan pengusaha lainnya agar paling tidak mendapatkan dukungan positif 
Bustanul Arifin

\section{DAFTAR PUSTAKA}

Abdurrahman Wahid, Pondok Pesantren Masa Depan, dalam Pesantren Masa Depan : Wacana Pemberdayaan dan Tansformasi Pesantren, (Jakarta : Pustaka Hidayah, 1999)

Amin Haedari. Panorama Pesantren dalam Cakrawala Modern. (Jakarta : Diva Pustaka, 2004).

Anason, Sejarah Masuknya Islam di Jawa, dalam Darrari Amin (ed), "Islam dan Kebudayaan Jawa", (Yogyakarta : Gajah Mada, cet. II, 2002)

Asrohah, Pelembagaan Pesantren

Azyumardi Azra, Jaringan Ulama Timur Tengah dan Kepulauan nusantara Abad XVII dan XVIII; Melacak akar-akar Pembaruan Pemikiran Islam Indonesia, (Bandung; Mizan,, 1998)

Dan Nimmo, Komunikasi Politik: Komunikator, Pesan dan Media, Bandung: Remaja Rosdakarya,EdisiTerjemahan oleh Tjun Surjaman, 1989

Departemen Agama RI, Al-Qur'an dan Terjemahnya (Bandung: CV Al-Jumanatul 'Ali, 2005

Faiqoh, Nyai Agen Perubahan di Pesantren. (Jakarta : Kurcica, 2003)

Gus Dur “Pesantren” : (WWW. Gus Dus Net. Libanon 2002).

Hadits hasan. HR Imam Ahmad dan Imam Darimi. Shahih Targhib wat-Tarhib no.: 2

Haidar Putra Daualy, Sejarah Pertumbuhan dan Pembaharuan Pendidikan Islam di Indonesia, (Jakarta: Kencana, 2009)

Karel A. Steenbrink, Pesantren, Madrasah, Sekolah; Pendidikan Islam dalam Kurun Modern, (Jakarta; LP3ES, 1986)

Kartini Kartono, Pemimpin dan Kepemimpinan (edisi baru). Jakarta: CV Rajawali, 2003

Koentjaraningrat, Pengantar Ilmu Antropologi, (Jakarta: Aksara Baru, 1980)

Muhammad Ali Hasyim, Kepribadian dan Dakwah Rasulullah dalam Kesaksian AlQur'an (Cet. I; Yogyakarta, Mutiara Pustaka, 2004)

Mujamil Qomar, Strategi Pendidikan Islam, Jakarta:Erlangga, 2013

Poerwodarminto, Kamus Umum Bahasa Indonesia, (Jakarta, Balai Pustaka, 2005)

Syekh Ali Mahfudz, Hidayat Al-Mursyidin, (Kairo: Dar al Kitab al-'Arabiy, 1952)

Falasifa, Vol. 10 Nomor 2 September 2019 | 18 
Strategi Pengembangan Lembaga Pendidikan Islam...

Veithzal Rivai Zainal, Kepemimpina dan Perilaku Organisasi, Jakarta: PT. Raja Grafindo Persada.

Wawancara, Susiati Alwy, Pengasuh Pondok Pesantren Al Falah Sumberdoko Kabupaten Kediri.

Wawancara, Suyadi, Guru SMP Negeri Weru Sukoharjo Kabupaten Klaten

Wawancara, Umaroni dan Chasmin, tanggal 19 Nopember 2016 (pada acara reuni akbar Madrasah Aliyah Tribakti Kediri). 